\title{
Leaky Waves on Periodically Slotted Travelling-Wave Aerials
}

\section{Arnbak, J.}

\section{Published in:}

1st European Microwave Conference

Link to article, DOI:

10.1109/EUMA.1969.331926

Publication date:

1969

Document Version

Publisher's PDF, also known as Version of record

Link back to DTU Orbit

\section{Citation $(A P A)$ :}

Arnbak, J. (1969). Leaky Waves on Periodically Slotted Travelling-Wave Aerials. In 1st European Microwave Conference (pp. 398-398). IEEE. https://doi.org/10.1109/EUMA.1969.331926

\section{General rights}

Copyright and moral rights for the publications made accessible in the public portal are retained by the authors and/or other copyright owners and it is a condition of accessing publications that users recognise and abide by the legal requirements associated with these rights.

- Users may download and print one copy of any publication from the public portal for the purpose of private study or research.

- You may not further distribute the material or use it for any profit-making activity or commercial gain

- You may freely distribute the URL identifying the publication in the public portal

If you believe that this document breaches copyright please contact us providing details, and we will remove access to the work immediately and investigate your claim. 
J. Arnbak

A class of microwave antennae can be derived from periodically slotted structures radiating continuously along their length. Assessment of the corresponding radiation patterns requires that the aperture field distribution and the propagation constant for the radiating line be known.

Usually, the rigorous Maxwellian eigenvalue problem based on continuity of tangential fields across any slot is too involved for an explicit solution. An approximate solution of the corresponding integral equation is often made by the collocation, or point-matching, method, i.e. by assuming an electric field in the slots and ensuring continuity of the magnetic field belonging to it in a number of discrete locations. The corresponding dispersion relation is reminiscent of a system of Kirchhoff equations for mesh currents related to the Floquet harmonics of the periodic structure. A more stringent dispersion relation may be obtained by enforcing local energy balance in any slot. Physically, this secures that no false sources are unintentionally introduced in the slots when an assumed field is stipulated. Mathematically, a dispersion relation stationary with respect to the field assumption results, not only in the case of surface waves, but also for radiating (leaky) waves. The dispersion relation corresponds to a complex power constraint arising from both sets of Kirchhoff equations for a network excited by Floquet harmonics. Since the surface admittances of the harmonics enter, driven by fictive voltage sources related to the Fourier coefficients of the slot field, the dispersion relation manifests itself as a transverse resonance condition.

The resulting expression takes into account edge conditions in slots and mutual coupling between any two slots. Contributions from slots well away from each other may often be summed asymptotically, leaving only the interaction between near neighbours for computer evaluation.

The procedure, or its dual counterpart, is suitable for finding the surface-wave and leaky-wave spectra of a rather wide class of periodic travelling-wave structures comprising slot arrays on waveguides and stripmodulated dielectric surfaces. Anomalies arising for instance from resonances (stopbands) or from coupling to the Floquet harmonics of higher order modes may be precisely located. From the near field of a leaky-wave distribution, the far fields can be calculated by a suitable integration.

As an example, calculations for a slot array on a circular waveguide loaded with a high-permittivity dielectric will be presented. A distinct leaky-wave beam may be used for frequency-scanning purposes.

J. Armbak is with the Laboratory of Electromagnetic Theory, the Technical University of Denmark, Lyngby, Denmark. 